\title{
Red Kidney Bean Powder Substituted Milk in Cinnamon Herbal Coffee: Consumer Perception, Sensory Properties and Nutrition Content
}

\author{
Noor Ariefandie Febrianto ${ }^{1 *}$, Khalimatus Sa'diyah' ${ }^{2)}$, and Tejasari ${ }^{2)}$ \\ 1)Indonesian Coffee and Cocoa Research Institute, J1. PB Sudirman No. 90, Jember 68118, Indonesia \\ ${ }^{2)}$ Faculty of Agricultural Technology, Jember University, Jl. Kalimantan No. 37, Jember 68121, Indonesia \\ ${ }^{*}$ Corresponding author: noor.ariefandie@gmail.com \\ Received: 18 June 2016 / accepted: 29 July 2016
}

\begin{abstract}
Consumer perspective of consuming coffee product has begun to shift not only for solely "pleasure" purpose, but also to consider its beneficial aspects. Red kidney bean (Phaseolus vulgaris L.) is a good source of fiber, protein and micronutrients to enhance the quality of beverages. This research was aimed to evaluate the effort to substitute milk with red bean powder in cinnamon herbal coffee and to study the enhancement of its nutrition content as well as the consumer perception and sensory properties. Red kidney bean powder was used to substitute milk powder and was blended with pre-mixed cinnamon coffee approximately $4 \%$, $8 \%, 12 \%, 16 \%$ and $20 \%$ to obtain ready to drink mixtures. The coffee and control were then subjected to consumer perception to 25 panelists and sensory analysis by three trained-panelists and were also analyzed for its relation with nutrition content. The result showed that the substitution of milk with red kidney bean powder up to $8 \%$ could still be accepted by untrained panelist and its addition up to $20 \%$ still acceptable by trained-panelists. Addition of red bean powder could improve protein content up to $89.3 \%$ and $133.0 \%$ of soluble fiber content compared to the coffee that used full milk powder. This result showed that red kidney bean powder could be used to substitute milk powder in coffee beverages since it significantly improved the nutrition value and resulted in good sensory properties.
\end{abstract}

Keywords: coffee mix, red kidney bean, protein, soluble fiber, sensory

\section{INTRODUCTION}

Nutrition enriched-coffee has become a popular new variety of coffee products which is intended to not only improve the acceptance of the coffee itself but also to improve its nutritional value. Herbal coffee is one of the most popular variant of coffee that generally accepted by consumers. It refers to the coffee product that has been enriched with herbs or spices or other supplement in purpose to improve its acceptance and enrich nutrition value of coffee (Dulloo et al., 1999; Roberts et al., 2005; Febrianto et al., 2015). The increasing market of herbal coffee occurred due to positive reports that stated that the combination of herbal and coffee could result in advantageous effect in body, including enhancing metabolic rates and other effects such as solving obesity issues and treating digestive problem (Dulloo et al., 1999; Roberts et al., 2005; Hoffman et al., 2006). 
Red kidney bean (Phaseolus vulgaris L.), commonly recognized by Indonesian as "kacang Jogo" is native to America and widely cultivated in Indonesia since the $16^{\text {th }}$ century (Rukmana, 2009). According to USDA (2007), red kidney bean is a good source of complex carbohydrate as well as soluble and insoluble fibers, vitamins, folic acid, calcium, phosphor, iron and protein. Further, USDA mentioned that red kidney bean contained approximately $22 \%$ protein, $61 \%$ carbohydrates and $15.2 \%$ fiber. Despite its high nutritious content, red bean is not regularly consumed by Indonesian since it is not a common staple food. Further, limited understanding regarding the correct method to cook the bean also become a factor that this bean is not consumed regularly due to the existence of innutritious compound such as phytic acid, phytoheamagglutinins, trypsin inhibitors, saponins and tannins (Shimelis \& Rakshit, 2007; Viswanathan \& Ho, 2014). As its role as subtitution product, red bean has been used to subtitute cereal flours in bread and low gluten aternative (Viswanathan \& Ho, 2014).

Milk powder has been usually used as natural dairy creamer due to its high content of fat (26-42\%) which could provide enough mouthfeel and consistency in coffee beverages (CAC, 2011). However, its role as dairy creamer has been replaced with other ingredient such as non-dairy creamer that derived from hydrogenated vegetable-based fats (oil) (Shurtleff \& Aoyagi, 2013). On other beverages, complex carbohydrates or polysaccharides are generally used as viscosity control agent to obtain desired mouthfeel. The use of polysaccharidessuch as soluble fiber from red bean offers several advantages compared to the use of milk, including reduced fat content, improve its nutrition content as the high concentration of soluble fiber, widen the range of consumption to whom which previously prohibited to consume dairy and non-dairy creamer due to religion and diet reason and also lower the production cost (Gancz et al., 2006; Roudsari et al., 2006; Mirhosseini et al., 2007; Rasnani et al., 2011).

Soluble dietary fiber (SDF) has been recognized as an advantageous component for human health, in spite of lack of nutritional value. Its unique matrix which possesses ability to absorb water, toxin, carcinogenic compound, sugar and low density lipoprotein, it has been known to reduce the potency of constipation, cardiovascular disease, and low density lipoprotein cholesterol problem (Pardede, 2013). Further, Jenkins et al. (2000) mentioned that consumption of SDF reduced postprandial glucose responses which could occur after consuming carbohydrate-rich meal, therefore lowering total and LDL cholesterol levels. The ability of SDF to form viscous, gel-like matrix help to slow gastric emptying, hindering macronutrient absorption from the gut and supporting colonic fermentation. On the other hand, the consumption of IDF consistently associated with reduced risk of type 2 diabetes problem (Schulze et al., 2007; de Munter et al., 2007). US Food and Drug Administration recommended total dietary fiber intakes were about $25 \mathrm{~g}$ daily, of which about $25 \%$ should be soluble fiber (US FDA, 2015).

Compared to abundant reports regarding herbal enriched coffee, there are limited studies currently known that have examined the physicochemically and sensory properties of coffee in which the milk powder was substituted by red bean powder. This research was aimed to evaluate the effort to substitute milk with red bean powder in cinnamon herbal coffee and to study consumer perception and sensory properties by trained panelists in relation with its nutrition content. It is expected that the outcome of this research could provide useful information regarding the physicochemical and sensory characteristics of coffee which used red kidney bean as the milk powder substitutes. 


\section{MATERIALS AND METHODS}

Robusta coffee powder obtained from Indonesian Coffee and Cocoa Research Institute (ICCRI), Jember, East Java, Indonesia, was mixed with cane sugar, cinnamon powder and non dairy creamer with a proportion of 29:58:3:10\% $(\mathrm{w} / \mathrm{w})$. The mixture was mixed until evenly distributed and addressed as premixed coffee.

Red kidney beans were purchased at a local market in form of dried beans. The bean were then washed and soaked in water with ratio of one $\mathrm{kg}$ beans to $10 \mathrm{~L}$ water for 24 hours. The soaked beans were then boiled for 8-10 minute. Boiled beans were then tempered at room temperature until cooled and then roasted in oven $\left(100^{\circ} \mathrm{C}\right)$ for one hour. The roasted beans were then ground and sieved in 200 mesh sieve. The powder obtained was then addressed as red bean powder.

Mixture of red kidney beans enrichedcoffee was prepared in the following proportions as mentioned in Table 1. Simple mixture design was used to determine the proportion of the factors (premixed coffee powder, red kidney bean powder, and milk powder). The level was fixed for premixed coffee powder $(80 \%)$, on the other hand, the levels of kidney bean powder, and milk powder were in the range of 0 to $20 \%$ with the total mixture was $100 \%$. The premixed coffee powder and either red bean powder and/or milk powder were mixed until evenly distributed powder was obtained. For physicochemical analysis, the coffee was brewed using hot water and stirred, then separated between supernatant and precipitate. The supernatant was then subjected into protein and soluble dietary fiber analysis. For sensory analysis, the powder was brewed using hot water prior to testing. The trial was done in triplicate.

The hedonic test was carried out using three different attributes, namely aroma, taste and overall acceptability. Twenty five grams of the mixture powder were brewed using $150 \mathrm{~mL}$ hot water. The measurement of panelist response was performed using 5 scales consisting of 1 (like very much), 2 (like), 3 (moderately like), 4 (dislike) and 5 (very dislike) (Soekarto, 1981). In analysis, the scale 1 will be scored $5 ; 2$ will be scored 4 ; 3 will be scored 3; 4 will be scored 2 and 5 will be scored 1 . Identity of the samples analyzed were randomized using 3 random numbers to avoid a bias. The hedonic test was carried out by 25 panelists.

The sensory analysis was done based on the method used in post-harvest laboratory of ICCRI based on modified SCAA (Specialty Coffee Association of America) cupping protocol. Twenty five grams of the mixture powder were brewed using $150 \mathrm{~mL}$ hot water and then evaluated on the following attribute: fragrance, aroma, flavor, body, sweetness, bitterness, astringency, and aftertaste. Four trained panelists were employed to analyze the mixtures based on 0 to 10 score method. The score was used to evaluate

Table 1. Proportions of premixed coffee, red bean and milk powder

\begin{tabular}{lccc}
\hline \multirow{2}{*}{ Mixtures } & \multicolumn{1}{c}{ Proportions, $\%$} \\
\cline { 2 - 4 } & Premixed coffee & Red bean powder & Milk powder \\
\hline Control & 80 & 0 & 20 \\
Formula 1 & 80 & 4 & 16 \\
Formula 2 & 80 & 8 & 12 \\
Formula 3 & 80 & 12 & 8 \\
Formula 4 & 80 & 16 & 4 \\
Formula 5 & 80 & 20 & 0 \\
\hline
\end{tabular}


the quality of each attribute. The score 0 represented inconsumable, 1-2 (very bad), 3-4 (bad), 5-6 (neutral), 7-8 (good) and 9-10 excellent. Data obtained was then presented in spider web diagram.

Protein content was analyzed based on the method of Kjeldahl (AOAC, 2005). On the other hand, analysis of soluble dietary fiber was carried out based on the method of Asp et al. cit. Nollet (2004) with slight modification. The result was presented in percentage of enrichment, in which it represented how many percent of the variable analyzed had improved compared to that of the control which noted as $0 \%$ enrichment.

Effectiveness index method by Degarmo et al. (1984) was employed to choose the best formulation based on the result of hedonic test. The effectiveness was determined using the weight to value variable (BV) and weight of normal $(\mathrm{BN})$ index. From the value obtained, the value of effectiveness $(\mathrm{Ne})$ was calculated using the formula below:

Value of effectiveness $=($ Treatment value - Worst value) / (Best value - Worst value)

Total value $(\mathrm{Nh})$ was calculated by multiplying the BN with Ne. Formulations with highest effectiveness index was choosen as the best treatment.

The result of nutrition content analysis and sensory analysis was presented descriptively using line and spider web graphic. Pearson correlation analysis $(\mathrm{p}<0.05)$ was done to analyze the correlation between nutrition content with tastes characteristic.

\section{RESULTS AND DISCUSSION}

\section{Nutrition Content and Sensory Properties}

Protein content of control coffee premix was $18.6 \mathrm{mg} / \mathrm{mL}$ in which the substitution of milk powder with red bean powder resulted in significant percentage of enrichment that were in range of $17.3 \%$ to $89.3 \%$ compared to control or approximately in range of 21.8 to $35.1 \mathrm{mg} / \mathrm{mL}$ (Figure 1). Analysis of milk powder and red bean powder itself resulted in protein content of $10.2 \%$ and $19.4 \%$, respectively, thus it is reasonable that the addition of red bean powder as a milk powder substitute in the mixtures could enhance the protein content of the coffee. In agreement with the report of Lusiyatiningsih \& Asngad (2014), addition of red bean in the product could result in higher content of protein due to its higher content of protein compared to other cereals such as corn and rice bran. Further, red kidney bean has been found to contain relatively high concentrations of essential amino acids such as lysine, leucine, phenylalanine, valine and isoleucine as much as $5.8 \%, 3 \%, 2 \%, 2 \%$ and $1.7 \%$ of total protein or $1.323,693,469,454$, and $383 \mathrm{mg} /$ $100 \mathrm{~g}$ red bean, respectively (Kay, 1979). In assumption to normal coffee serving and consumption ( 3 cups a day at $150 \mathrm{~mL} / \mathrm{serving}$ ), the consumption of red bean enriched coffee could fulfill as much as $15.3 \%$ to $24.7 \%$ of recommended dietary allowances (DRA) based on the regulation of Indonesian Ministry of Health (2013). House (2010) mentioned that red kidney bean was a good source of protein due to its moderate protein efficiency ratio (PER) (PER 1.55 compared to casein's PER 2.50). The higher the PER, the higher the potency of the protein contribute to mass gain to the consumer.

Soluble dietary fiber (SDF) content of the mixtures were also found to be enriched compared to control which were in range of $18.64 \%$ to $132.97 \%$ or approximately $0.82 \mathrm{~g}$ to $1.625 \mathrm{~g}$ of SDF per serving (control $0.69 \mathrm{~g}$ ) (Figure 1). In general, SDF content of the mixtures was increasing as the increase of red bean powder percentage. These values were around $6 \%$ to $14 \%$ of recommended dietary allowances, in which the consumption of red bean powder enriched-coffee could 
fulfill at least $7.2 \%$ of the RDA (calculation based on Formula 1-4\% addition of red bean powder, in assumption of 3 cups a day with $25 \mathrm{~g}$ coffee each serving and RDA of fiber on average $34.6 \mathrm{~g} /$ person/day). Based on the report of Jahari \& Sumarno cit. Nainggolan \& Adimunca (2005), average consumption of fiber in Indonesia was still in the range of 9.9 to $10.7 \mathrm{~g} /$ person/day or approximately only $31 \%$ of RDA. Low intake of fiber most likely caused by a shifting trend in the consumption pattern of low fat, high fiber and carbohydrate intake to high protein and fat but low carbohydrate and fiber consumption (Nainggolan \& Adimunca, 2005). On the other hand, compared to milk powder which still contribute to calorie level of the beverage, the substitution of it with red bean powder contribute no calories to our diet. However, its function to support microorganism population in colon helps microorganism to release advantageous metabolites to meet human energy requirements (Turner \& Lupton, 2011).
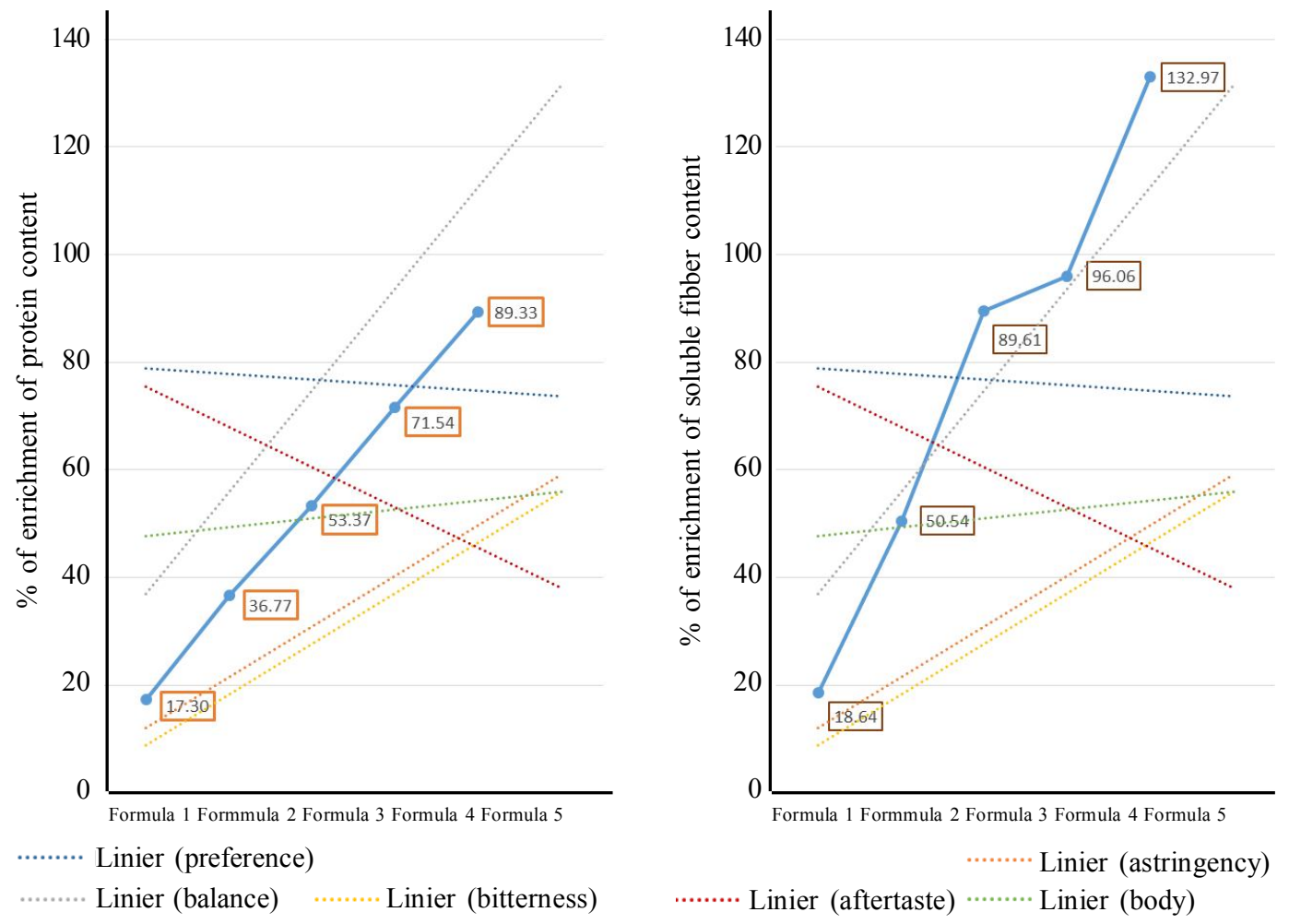

\begin{tabular}{|c|c|c|c|c|c|c|}
\hline \multirow{2}{*}{ Variable } & \multicolumn{5}{|c|}{ Pearson correlation coefficient } \\
\hline & Astringency & Balance & Bitterness & Aftertaste & Body & Preference \\
\hline Protein content & $0.923^{*}$ & $0.925^{*}$ & 0.656 & -0.735 & 0.150 & -0.132 \\
\hline $\begin{array}{c}\text { Soluble Fiber } \\
\text { Content }\end{array}$ & $0.862^{*}$ & $0.947^{*}$ & 0.671 & -0.709 & 0.257 & -0.149 \\
\hline
\end{tabular}

Figure 1. Comparison of percentage of enrichment of protein content (left) and soluble dietary fiber content (right) between coffee mixtures compared to control ( $0 \%$ enrichment) and its correlation with tastes characteristic based on Pearson correlation analysis. [Composition of premix coffee: red bean powder: milk powder $=$ Formula 1 (80:4:16), Formula 2 (80:8:12), Formula 3 (80:12:8), Formula 4 (80:16:4), Formula 5 (80:20:0) see Table 1]

$\left({ }^{*}\right.$ represent significantly different at $\left.\mathrm{p}<0.05\right)$. 
Codex Alimentarius Commission categorized the term of dietary fiber into three categories namely, "naturally occurred in the food consumed"; "obtained by means of physical, chemical and enzymatic"; and "synthetic carbohydrate monomer". However, despite various sources of dietary fiber, the experts still recommended that fiber should be obtained from the consumption of food due to its nutritional benefits of micronutrients and bioactive compound contained in the food (CAC, 2010; Turner \& Lupton, 2011). The sources of the dietary fiber recommended are whole grains, legumes, vegetables, nuts, seeds and fruits. Red kidney bean itself contains micronutrients such as thiamin, riboflavin, niacin, pantotenic acid, vitamin B-6 and folic acid, and numerous minerals in addition to its high content of protein and dietary fiber (USDA, 2016).

In relation with taste characteristics, we found that the enrichment of protein content significantly correlated positively with the improvement of astringency and balance quality of the mixtures (Figure 1). Further, it also improved the quality of bitterness and body, in spite of insignificantly. In general, the substitution of milk in coffee beverages with red bean powder lowered the quality of aftertaste and preference. Similar to the correlation of protein content with taste characteristics, soluble fiber content also showed that the substitution of milk powder with red bean powder improved the quality of astringency and balance characteristic (significantly), and improved the body and bitterness quality (insignificantly). However, it lowered the aftertaste quality and preference of the panelist (Figure 1).

\section{CONSUMER PERCEPTION AND SENSORY ANALYSIS}

Hedonic test results as presented in Figure 2 showed that the use of red bean powder as milk powder substitute in coffee beverages lowered consumer acceptance in all attributes. In general, the value of the responses varied in a range between 2.48 to 3.68 for aroma, 2 to 3.6 for taste and 2.72 to 3.64 for overall acceptance, represented responses from dislike to moderately like and "almost" like preferences. The control $(80 \%$ premix coffee and $20 \%$ milk powder) possessed the highest point in almost every attribute compared to the mixtures, except for overall preferences attribute that slightly outmatched with Formula 2 (control $=3.6$, Formula $2=3.64$ ). We found that the substitution of milk powder with high concentration of red bean powder (more than 12\%) significantly reduced consumer acceptance, in which the response fell from moderately like to dislike. This suggests that substitution of milk powder with red bean powder in high concentration cannot be implemented because it is useless since the consumer will not accept it. In session of hedonic test, the samples were introduced and designated as coffee mix product, in which the common coffee mix product should at least contain coffee, sugar, non dairy creamer and milk powder. Kemp et al. (2009) previously mentioned that consumer judgment is usually influenced by their common perception of the product and the panelists tend to use the common coffee mix product as their standard for scoring. Thus, it is reasonable that the panelists gave a lower acceptance of the products that have different characteristics from their common perspective of coffee mix product.

Our result of hedonic test showed that Formula 1,2, and 3 were still considered to give good acceptance to the consumers. Formula 2 ( $8 \%$ of red bean powder) showed similarity in the pattern of panelists responses to control, whereas Formula 1 and 3 showed significantly lower values compared to Formula 2 and control. The result of effectiveness index 




Figure 2. Scoring result of hedonic test of red bean substituted-coffee on different formulation of mixtures. [Composition of premix coffee: red bean powder: milk powder $=$ Control (80:0:20), Formula 1 (80:4:16), Formula 2 (80:8:12), Formula 3 (80:12:8), Formula 4 (80:16:4), Formula 5 (80:20:0) see Table 1]

analysis showed that the control obtained 0.99 , the highest compared to others, whereas Formula 2 obtained 0.92 effectiveness index, followed by Formula 1 (0.73), Formula 3 (0.45), Formula 4 (0.21) and Formula $5(0)$. Based on the report of Febrianto et al. (2015), lower acceptance of the mixture samples compared to control could be contributed by unfamiliar sensation that was experienced by panelist during the tasting session. The most notable sensation of red bean enriched-coffee was the occurrence of grassy-bean taste and aroma that usually noted in legumes and beans derived-products. These flavors were reported to be composed by the aldehydes, alcohol, ketones and furans due to the activity of lipoxigenase or oxidative rancidity of unsaturated fatty acids (Kaneko et al., 2011; Lee et al., 2003). This phenomenon was in agreement with the result obtained in sensory analyses by trained panelists, which stated that the fragrance, aroma and flavor of the mixtures were significantly lower compared to control (Figure 3). The panelists stated that the mixtures contained slightly unpleasant flavor that should not occur in good coffee such as grassy-bean and cereal off-flavor, thus reduced the score on respective attributes.

Previous report by Heng et al. (2006) stated that nonvolatile compounds in soybean such as phenolic acid, isoflavone, saponin, and tetrol contribute to bitterness and astringency in the soybean derived-products. These factors were suspected to reduce consumer acceptance in the taste of the mixtures compared to control due to relatively higher levels of astringency and bitterness. However, trained panelists found that the addition of red bean powder improved the quality of bitterness 


\section{Febrianto et al.}

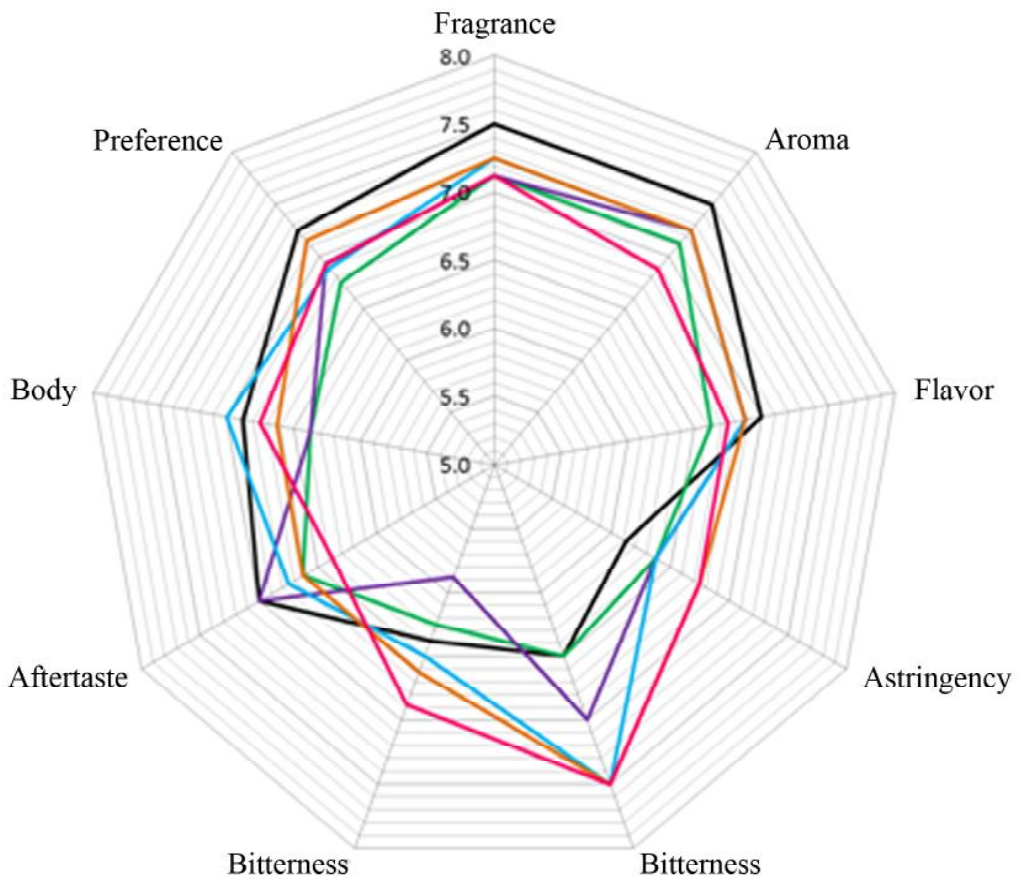

- Control - Formula 1 - Formula 2 -Formula 3 -Formula 4 -Formula 5

Figure 3. Scoring result of trained panelists sensory analysis of red bean substituted-coffee on different formulation of mixtures. [Composition of premix coffee: red bean powder: milk powder $=$ Control (80:0:20), Formula 1 (80:4:16), Formula 2 (80:8:12), Formula 3 (80:12:8), Formula 4 (80:16:4), Formula 5 (80:20:0) see Table 1]

and astringency since it balanced the sweet and bitter properties of the mixtures. Different response between untrained and trained panelist was suspected due to the different perspective in addition to the purpose of the analysis itself. Untrained panelist tended to choose the coffee that fulfilled their requirements for pleasure purpose, in addition to the consumer expectation of sweet and high bodied coffee beverages as they found in common coffee mix products. On the other hand, trained panelists tended to identify and quantify the sensory properties of a product instead of their preferences to the respective products (Stone et al., 1997). Since the trained panelists were trained for coffee sensory analysis, their standard of analysis was based on their perception of "black coffee", in which the balance between sweet- ness, body, bitterness, and astringency is considered as an important aspect. This is also the reason that red bean substitutedcoffee possessed a significantly better quality of balance compared to control as evaluated by trained panelists.

Davids (2003) previously mentioned that a body is a term used to describe the mouthfeel and often to be related to the texture or heaviness of the coffee. Trained panelists found that the body of the mixtures generally lower compared to control, except for Formula 3. In accordance with the result of SDF analysis, the increasing of SDF, especially fiber with high water holding capacity could result in highly viscous solution (Wursch \& Pi-Sunyer, 1997). However, the increase in SDF content with the addition of red bean powder still could not 
match the body characteristic of milk enriched coffee. Codex Alimentarius Commission (2011) stated that whole milk powder or generally considered as full cream powder contain at least $26 \%$ fat (maximum $42 \%$ ) compared to red bean powder which only contain about 1 or $2 \%$ of fat, thus the addition of milk powder into beverages could improve the body of it due to its creamy mouthfeel resulted by high fat content.

\section{CONCLUSIONS}

Substitution of milk powder with red bean powder in coffee beverages has been successfully carried out in this experiment. The use of red bean powder instead of milk powder in coffee beverages could significantly improve its soluble protein and dietary fiber content, although it lowers the consumer's acceptance. The substitution of milk powder with red bean powder up to ratio 8:12 found to give a good result. However, the substituting of milk powder with red bean powder with the ratio of 12:8 was found to give the best effectiveness index and acceptance by panelists compared with other mixtures. The major drawback of the addition of red bean powder was the occurrence of grassy-bean flavor and the increasing of bitterness and astringency, therefore the more addition of red bean powder to the coffee significantly lower consumer acceptance. The result concluded that the substitution of milk powder with red bean powder can be potentially applied as an option to develop coffee beverages with healthy benefits product.

\section{ACKNOWLEDGEMENT}

The authors would like to express their gratitude to the technicians in Post-Harvest Technology Laboratory, ICCRI and Jember University's Laboratory and also anonymous reviewers for their contribution to the perfection of this manuscript.

\section{REFERENCES}

AOAC (2005). Official Method of Analysis of the Association of Official Analitycal Chemists. 18th ed. AOAC International, Maryland, USA.

CAC (2010). Codex Alimentarius (CODEX) Guideliness on Nutrition Labelling CAC/GL 2-1985 as last Amended 2010. Joint FAO/WHO Food Standards Programme, Secretariat of the CODEX Alimentarius, Rome, Italy.

CAC. (2011). Milk and Milk Products $2^{\text {nd }}$ Edition. Food and Agriculture Organization, Rome, Italy.

Davids, K. (2003). Home Coffee Roasting: Romance \& Revival. St. Martin Press, London, UK United Kingdom.

de Munter, J.S.; F.B. Hu; D. Spiegelman; M. Franz \& R.M. van Dam (2007). Whole grain, bran, and germ intake and risk of type 2 diabetes: a prospective cohort study and systematic review. PLOS Medicine, 4, 1485-1395.

Dulloo, A.G.; C. Duret; D. Rohrer; L. Girardier; N. Mensi; M. Fathi \& P. Chantre (1999). Efficacy of a green tea extract rich in catechin polyphenols and caffeine in increasing 24-h energy expenditure and fat oxidation in humans. American Journal of Clinical Nutrition, 70, 1040-1045.

Febrianto, N.A.; V.M. Rizki \& Djumarti (2015). Development of cardamom herbal coffee beverages: A study of physicochemical characteristics and consumer perception towards sensory properties. Pelita Perkebunan, 31, 49-58.

Gancz, K.; M. Alexander \& M. Corredig (2006). In situ study of flocculation of whey protein-stabilized emulsions caused by addition of high methoxyl pectin. Food Hydrocolloids, 20, 293-298.

Heng, L.; J.P. Vincken; G. van Koningsveld; A. Legger; H. Gruppen \& T. van Boekel; 
J. Roozen \& F. Voragen (2006). Bitterness of saponins and their content in dry peas. Journal of the Science of Food and Agriculture, 86, 1225-1231.

Hoffman, J.R.; J. Kang; N.A. Ratamess; P.F. Jennings; G. Mangine \& AD. Faigenbaum (2006). Thermogenic effect from nutricially enriched coffee consumption. Journal of the International Society of Sports Nutrition, 3, 35-41.

House, J.D. (2010). Protein Quality and Canadian Pulses: Finding the Right Balance. University of Manitoba Press, Canada.

Indonesian Ministry of Health (2013). Peraturan Menteri Kesehatan Republik Indonesia Nomor 75 Tahun 2013 Tentang Angka Kecukupan Gizi yang Dianjurkan bagi Bangsa Indonesia. Kementerian Kesehatan Republik Indonesia, Jakarta, Indonesia.

Jenkins D.J.; C.W. Kendall; M. Axelsen; L.S. Augustin \& V. Vuksan (2000). Viscous and nonviscous fibres, nonabsorbable and low glycaemic index carbohydrates, blood lipids and coronary heart disease. Current Opinion in Lipidology, 11, 49-56.

Kaneko, S.; K. Kumazawa \& O. Nishimura (2011). Studies on the key aroma compounds in soy milk made from three different soybean cultivars. Journal of Agricultural and Food Chemistry, 59, 12204-12209.

Kemp, S.E.; T. Hollowood \& J. Hort (2009). Sensory Evaluation a Practical Handbook. A John Wiley \& Sons, Ltd. Singapore.

Lee, J.Y.; S. Min; E.O. Choe \& D.B. Min (2003). Formation of volatile compounds in soy flour by singlet oxygen oxidation during storage under light. Journal of Food Science, 68, 1933-1937.

Lusiyatiningsih, T. \& A. Asngad (2014). Uji Kadar Serat, Protein, dan Sifat Organoleptik pada Tempe dari Bahan Dasar Kacang Merah (Phaseolus vulgaris L.) dengan Penambahan Jagung dan
Bekatul. Artikel Publikasi Ilmiah. Universitas Muhammadiyah Surakarta, Solo, Indonesia.

Mirhosseini, H.; C.P. Tan; N.S.A. Hamid \& S. Yusof (2007). Modeling the relationship between the main emulsion components and stability, viscosity, fluid behavior, zetapotential and electrophoretic mobility of orange beverage emulsion using response surface methodology. Journal of Agriculture and Food Chemistry, 55, 7659-7666.

Nainggolan, O. \& C. Adimunca (2005). Diet sehat dengan serat. Cermin Dunia Kedokteran, 147, Departemen Kesehatan RI, Jakarta.

Nollet \& M.L. Leo (2004). Handbook of Food Analysis. Marcel Dekker, Inc, NewYork, USA.

Pardede, E. (2013). Tinjauan komposisi kimia buah dan sayur: Peranan sebagai nutrisi dan kaitannya dengan teknologi pengawetan dan pengolahan. Jurnal VISI, 21, 1452-1463.

Rasnani, N.M.; H. Mirhosseini; B.S. Baharin \& C.P. Tan (2011). Effect of $\mathrm{pH}$ on physicochemical properties and stability of sodium caseinate-pectin stabilized emulsion. Journal of Food, Agriculture \& Environment, 9, 129-135.

Roberts, A.T.; L. de Jonge-Levitan; C.C. Parker $\&$ F.L. Greenway (2005). The effect of an herbal supplement containing black tea and caffeine on metabolic parameters in humans. Alternative Medicine Review, 10, 321-325.

Roudsari, M.; A. Nakamura; A. Smith \& M. Corredig (2006). Stabilizing behavior of soy soluble polysaccharide or high methoxyl pectin in soy protein isolate emulsions at low pH. Journal of Agriculture and Food Chemistry, 54, 1434-1441.

Rukmana, R. (2009). Budidaya Buncis. Penerbit Kanisius, Jakarta, Indonesia.

Schulze, M.B.; M. Schulz; C. Heidemann; A. Schienkiewitz; K. Hoffmann \& H. Boeing (2007). Fiber and magnesium 
intake and incidence of Type 2 diabetes: A prospective study and meta-analysis. Archive in Internal Medicine, 167, 956-965.

Shimelis, E.A. \& S.K. Rakshit (2007). Effect of processing on antinutrients and in vitro protein digestibility of kidney bean (Phaseolus vulgaris L.) varieties grown in East Africa. Food Chemistry, 103, 161-172.

Shurtleff, W. \& A. Aoyagi (2013). History of Non-Dairy Whip Topping, Coffee Creamer, Cottage Cheese, and Icing/ Frosting (With and Without Soy) (1900-2013): Extensively Annotated Bibliography and Sourcebook. Soyinfo Center, California, USA.

Soekarto, S. (1981). Penilaian Organoleptik. Institut Pertanian Bogor Press, Bogor, Indonesia.

Stone, H.; J. Sidel; S. Oliver; A. Woolsey \& R.C. Singleton (1997). Sensory evaluation by quantitative descriptive analysis, p. 15. In: Gacula Jr., M.C (Ed.) Descriptive Sensory Analysis in Practice. Food \& Nutrition Press, Inc., Connecticut, USA.
Turner, N.D. \& J.R. Lupton (2011). Dietary fiber. Advance in Nutrition, 2, 151-152.

US FDA (2015). Code of Federal Regulations 21CFR101-Food and Drugs. Food and Drug Administration, USA.

USDA (2007). Beans, Kidney, California Red, Mature Seeds, Raw. United States Department of Agriculture National Nutrient Database for Standard Reference, Release 20. USDA, USA.

USDA (2016). Beans, Kidney, California Red, Mature Seeds, Raw. United States Department of Agriculture National Nutrient Database for Standard Reference, Release 28. USDA, USA.

Viswanathan, K. \& P. Ho (2014). Fortification of white flat bread with sprouted red kidney bean (Phaseolus vulgaris). Acta Scientiarum Polonorum Technologia Alimentaria, 13, 27-34.

Wursch, P. \& F.X. Pi-Sunyer (1997). The role of viscous soluble fiber in the metabolic control of diabetes: a review with special emphasis on cereals rich in $(\beta$ glucan). Diabetes Care, 20, 1774-1780.

$* * 0 * *$ 